1108

\title{
$\mathrm{Ti}-\mathrm{Ni}$ 系形状記憶合金のキャビテーション壊食特性*
}

\author{
服部修 次*1, 田井中敦*2
}

\section{Cavitation Erosion of Ti-Ni Base Shape Memory Alloys}

\author{
Shuji HATTORI ${ }^{* 3}$ and Atsushi TAINAKA \\ ${ }^{* 3}$ Department of Mechanical Engineering. University of Fukui, \\ 3-9-1 Bunkyo, Fukui-shi, Fukui, 910-8507 Japan
}

\begin{abstract}
Cavitation erosion tests were carried out by using $\mathrm{Ti}-\mathrm{Ni}$ base SMA (shape memory alloy) with the addition of the third element $(\mathrm{Co}, \mathrm{Fe}, \mathrm{V}$ and $\mathrm{Cu})$ to $\mathrm{Ti}-\mathrm{Ni}$ SMA. The erosion resistance and the mechanism were discussed. Erosion resistance of $\mathrm{Ti}-\mathrm{Ni}$ base SMAs is about $1 / 4$ to $1 / 2$ as compared with that of $\mathrm{Ti}-\mathrm{Ni} \mathrm{SMA}$, but it is about 6 to 16 times as high as that of SUS 304. It was found that the erosion resistance for martensite phase is superior to that for austenite phase. It was concluded that the erosion resistance of $\mathrm{Ti}-\mathrm{Ni}$ base SMAs depends mainly on the defect density and the removal rate of eroded area.
\end{abstract}

Key Words: Cavitation Erosion, Cavitation, Nonferrous Metal, Hardness, and Shape Memory Alloys

\section{1. 緒言}

キャビテーション壊食は, ポンプ, 水車, トルクコ ンバータなどの流体機械をはじめ, 船用プロペラ, バ ルブ，ディーゼルエンジンのシリンダライナなど多く の産業機械や部材で液体が接している筒所に生じて, 材料表面を海綿状に損傷する現象である。キャビテー ション壊食の発生は, 機器の性能低下や寿命低下をも たらすだけでなく, 部材の破壊にもつながる重要な問 題である.キャビテーション壊食の発生を抑制するこ とが困難な場合には，耐壊食性に優れている材料を選 択する必要がある.

これまでの報告の中で，耐壊食性に優れた工業材料 としてコバルト合金のステライトが挙げられる(1). し かし, ステライトは原子力発電プラント用の部材とし て使用する場合には, Co が原子炉中に流出し, 放射線 を受けると放射化してプラント内の放射線量を増加さ せるという問題がある。そこで, Co を含まない耐壊 食性に優れた代替材料が望まれている。

* 原稿受付 2005 年 9 月 20 日.

*1 正員, 福井大学工学部 (画910-8507 福井市文京 3-9-1).

*2 福井大学大学院工学研究科.

E-mail : hattori@mech.fukui-u.ac.jp
服部ら ${ }^{(2)(3)}$ は, $\mathrm{Ti}-\mathrm{Ni}$ 形状記憶合金が双晶変形とす ベりの組合せで塑性変形するために，すべりのみで塑 性変形する金属に比べて極めて壊食されにくく，また 被覆材についてもバルク材とほぼ同等の耐壊食性を示 すことを報告した． $\mathrm{Ti}-\mathrm{Ni}$ 形状記憶合金への第三元 素の添加は機械的性質や変態温度を変化させ, 常温で オーステナイトの状態にすることができる(4). 佐久間 ら (5) は, 第三元素を添加した $\mathrm{Ti}-\mathrm{Ni}$ 系形状記憶合金 の噴流衝突によるエロージョン試験を行い, $\mathrm{Ti}-\mathrm{Ni}$ 系 形状記憶合金の壊食形態 (試験片断面上の損傷面積) は 合金の種類による差はほとんどなく, 耐エロージョン 性は硬さの増大とともに増加すると報告している。し かし，第三元素を含む $\mathrm{Ti}-\mathrm{Ni}$ 系形状記憶合金のキャ ビテーション壊食特性は，まだ十分に明らかにされて いない.

本研究では, Ti-Ni 形状記憶合金に Co, Fe, V, Cu の第三元素をそれぞれ添加した合金を用いてキャビテ ーション壊食試験を行い, オーステナイト系ステンレ ス鋼 SUS 304, 第三元素を含まない $\mathrm{Ti}-\mathrm{Ni}$ 形状記憶 合金，ステライトと比較して壊食機構を検討するとと もに耐壊食性を考察した。 


\section{2. 試験材料および試験方法}

試験材料は $\mathrm{Ti}-\mathrm{Ni}$ 形状記憶合金に第三元素として $\mathrm{Co}, \mathrm{Fe}, \mathrm{V}, \mathrm{Cu}$ 添加した $\mathrm{Ti}-\mathrm{Ni}$ - $\mathrm{Co}, \mathrm{Ti}-\mathrm{Ni}-\mathrm{Fe}$, $\mathrm{Ti}-\mathrm{Ni}-\mathrm{V}$ ，および $\mathrm{Ti}-\mathrm{Ni}-\mathrm{Cu}$ であり，参照材料には第 三元素を含まない $\mathrm{Ti}-\mathrm{Ni}$ 形状記憶合金を用いた。 以 下，第三元素を含む $\mathrm{Ti}-\mathrm{Ni}$ 形状記憶合金を「 $\mathrm{Ti}-\mathrm{Ni}$ 系形状記憶合金」，第三元素を含まないものを「Ti$\mathrm{Ni}$ 形状記憶合金」と区別する。 Ti- $\mathrm{Ni}$ 系形状記憶合 金は大同特殊鋼(株)上り, Ti- $\mathrm{Ni}$ 形状記憶合金は(株) 古河テクノマテリアルより提供を受けた。さらに, オ ーステナイト系ステンレス鋼 SUS 304, ステライト ST 6 も参照材料として用いた. 表 1 に各種の形状記 憶合金, 表 2 に参照材料の化学成分を示す.添加され ている第三元素は $\mathrm{Cu}$ の場合は $8 \%$ 程度であるが, そ の他のものは $1.5 \%$ 未満とごく少量である.

Table 1 Chemical components of $\mathrm{Ti}-\mathrm{Ni}$ base shape memory alloys

\begin{tabular}{|c|c|c|c|c|c|c|c|c|}
\hline Material & $\mathrm{Ti}$ & $\mathrm{Ni}$ & $\mathrm{Co}$ & $\mathrm{Fe}$ & $\mathrm{V}$ & $\mathrm{Cu}$ & $\mathrm{C}$ & {$[\mathrm{O}]$} \\
\hline Ti-Ni-Co & Bal. & 54.40 & 1.44 & - & - & - & 0.060 & 0.045 \\
\hline Ti-Ni-Fe & Bal. & 55.90 & - & 0.23 & - & - & 0.018 & 0.034 \\
\hline Ti-Ni-V & Bal. & 55.74 & - & - & 0.47 & - & 0.012 & 0.059 \\
\hline Ti-Ni-Cu & Bal. & 46.65 & - & - & - & 8.30 & 0.009 & 0.034 \\
\hline
\end{tabular}

Table 2 Chemical composition of the reference materials

\begin{tabular}{|c|c|c|c|c|c|c|c|}
\hline Material & $\mathrm{Ti}$ & $\mathrm{Ni}$ & $\mathrm{Co}$ & $\mathrm{Fe}$ & $\mathrm{V}$ & $\mathrm{Cu}$ & $\mathrm{C}$ \\
\hline $\mathrm{Ti}-\mathrm{Ni}$ & 44.92 & 55.08 & - & - & - & - & - \\
\hline Material & $\mathrm{C}$ & $\mathrm{Si}$ & $\mathrm{Mn}$ & $\mathrm{P}$ & $\mathrm{S}$ & $\mathrm{Cr}$ & $\mathrm{Ni}$ \\
\hline SUS304 & 0.071 & 0.48 & 1.21 & 0.025 & 0.022 & 18.47 & 8.21 \\
\hline
\end{tabular}

\begin{tabular}{|c|c|c|c|c|c|}
\hline Material & $\mathrm{Co}$ & $\mathrm{Cr}$ & $\mathrm{W}$ & $\mathrm{Ni}$ & $\mathrm{Fe}$ \\
\hline ST6 & 62.75 & 28.0 & 4.0 & 3.0 & 2.0 \\
\hline
\end{tabular}

表 3 は試験材料の機械的性質, マルテンサイト変態 開始温度および熱処理条件を示したものである。オー ステナイト状態の $\mathrm{Ti}-\mathrm{Ni}$ 系形状記憶合金は, マルテ ンサイト状態と比較して横弾性係数 (せん断弾性係数) および $0.2 \%$ 耐力が大きくなっているが, 引張強さは ほとんど変わらない. Ti-Ni-Co, Ti-Ni-Fe, Ti-Ni$\mathrm{V}$ は常温でオーステナイト状態, $\mathrm{Ti}-\mathrm{Ni}-\mathrm{Cu}$ と $\mathrm{Ti}-\mathrm{Ni}$ 形状記憶合金はマルテンサイト状態である.なお，ビ ッカース硬さは室温で荷重 $200 \mathrm{gf}$, 保持時間 $15 \mathrm{~s}$ で計 測した。試験片の大きさは，ほぼ $25 \mathrm{~mm} \times 25 \mathrm{~mm} \times 5$ $\mathrm{mm}$ である. 試験面はエメリー紙の\#1200で研磨し た後, バフ仕上げにより鏡面にした。

キャビテーション壊食試験は, ASTM G 32-98(6) に基づいて製作した図 1 に示す磁わい振動装置を用い て, 静置試験片法で行った，振動子の増幅ホーンの先

Table 3 Mechanical properties of materials, transformation temperature and quenching heat treatment of materials

\begin{tabular}{|c|c|c|c|c|c|c|c|c|c|c|}
\hline \multicolumn{2}{|c|}{ Material } & $\begin{array}{c}\text { Heat } \\
\text { treatment }\end{array}$ & $\begin{array}{c}\text { Density } \\
\mathrm{kg} / \mathrm{m}^{3}\end{array}$ & $\begin{array}{l}\text { Modulus of } \\
\text { transverse } \\
\text { elasticity } \\
\mathrm{GPa}\end{array}$ & $\begin{array}{c}\text { Young's } \\
\text { modulus } \\
\text { GPa }\end{array}$ & $\begin{array}{l}0.2 \% \\
\text { proof } \\
\text { stress } \\
\mathrm{MPa}\end{array}$ & $\begin{array}{c}\text { Tensile } \\
\text { strength } \\
\mathrm{MPa}\end{array}$ & $\begin{array}{c}\text { Elon- } \\
\text { gation } \\
\%\end{array}$ & $\begin{array}{l}\text { HV0.2 } \\
\text { (room } \\
\text { temp.) }\end{array}$ & $\begin{array}{c}\text { Martensitic } \\
\text { transformation } \\
\text { start temp. } \\
{ }^{\circ} \mathrm{C}\end{array}$ \\
\hline \multirow{2}{*}{ Ti-Ni-Co } & Martensite & \multirow{2}{*}{$\begin{array}{c}900^{\circ} \mathrm{C}, 30 \mathrm{~min} \\
\text { WQ }\end{array}$} & \multirow{2}{*}{$6.39 \times 10^{3}$} & 11.8 & & 147 & 1470 & 50 & \multirow{2}{*}{282} & \multirow{2}{*}{-54} \\
\hline & Austenite & & & 27.0 & & 735 & 1320 & 20 & & \\
\hline Ti-Ni-Fe & Martensite & $900^{\circ} \mathrm{C}, 30 \mathrm{~min}$ & $6.42 \times 10^{3}$ & \multicolumn{5}{|c|}{ unknown } & 244 & 10 \\
\hline \multirow{2}{*}{ Ti-Ni-V } & Martensite & $900^{\circ} \mathrm{C}, 30 \mathrm{~min}$ & $60 \times 13^{3}$ & \multirow{2}{*}{\multicolumn{5}{|c|}{ unknown }} & 242 & 10 \\
\hline & Austenite & WQ & $0.38 \times 10$ & & & & & & & \\
\hline \multirow{2}{*}{ Ti-Ni-Cu } & Martensite & $900^{\circ} \mathrm{C}, 30 \mathrm{~min}$ & & 2.5 & & 83 & 1470 & 20 & \multirow{2}{*}{179} & \multirow{2}{*}{60} \\
\hline & Austenite & WQ & $6.41 \times 10^{-}$ & 23.5 & & 588 & 1470 & 20 & & \\
\hline \multirow{2}{*}{$\mathrm{Ti}-\mathrm{Ni}$} & Martensite & $500^{\circ} \mathrm{C}, 1 \mathrm{~h}$ & $615 \times 10^{3}$ & 8.8 & & 98 & 1270 & 50 & \multirow{2}{*}{210} & \multirow{2}{*}{40} \\
\hline & Austenite & WQ & $6.45 \times 10^{\circ}$ & 19.6 & & 588 & 1130 & 20 & & \\
\hline \multicolumn{2}{|c|}{ SUS304 } & $\begin{array}{c}1060^{\circ} \mathrm{C} ; 30 \mathrm{~min} \\
\text { WQ }\end{array}$ & $7.98 \times 10^{3}$ & & 197 & 294 & 618 & 62 & 198 & - \\
\hline \multicolumn{2}{|c|}{ ST6 } & - & $8.40 \times 10^{3}$ & & 206 & & 922 & & 466 & - \\
\hline
\end{tabular}


端に耐壊食性に優れた SUS 304 製の直径 $16 \mathrm{~mm}$ のデ イスクを取付け，このディスクと平行にすきま $1 \mathrm{~mm}$ (ダイヤルゲージで設定) 隔てて試験片を対向させて静 置した. 振動子の共振周波数は $19.5 \mathrm{kHz}$ で, ディス ク端面の全振幅 (peak to peak) は $50 \mu \mathrm{m}$ 一定とした. ディスクは 10 時間使用するごとに新しいものと交換 した，試験液はイオン交換水を用い, 液温は恒温装置 で $25^{\circ} \mathrm{C} \pm 1^{\circ} \mathrm{C}$ に保持した。試験片は, 所定時間ごとに 取り外し, アセトン中で超音波洗浄した後, 質量を精 密天科(感度 $0.01 \mathrm{mg}$ ) で測定した. 試験結果は質量減 少量を材料の密度で除して体積減少量を求め, 体積減 少量を試験面積 $\left(201 \mathrm{~mm}^{2}\right)$ で除した MDE(平均壊食 深さ)で整理した。壊食面の形状は非接触式表面形状 測定システム(キーエンス製 LMS-3 D：分解能 0.1 $\mathrm{mm}$, 測定間隔 $1.8 \mu \mathrm{m}$ ) で測定した。壊食面の観察は 走查形電子顕微鏡 $(\mathrm{SEM})$ で行った.

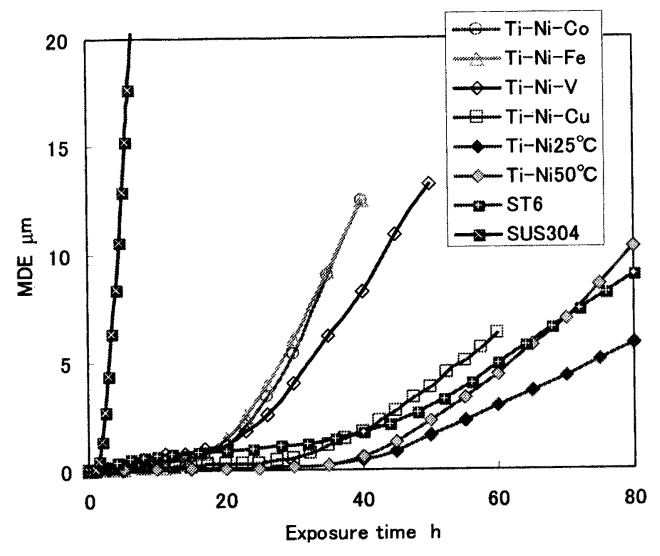

Fig. 2 MDE curves

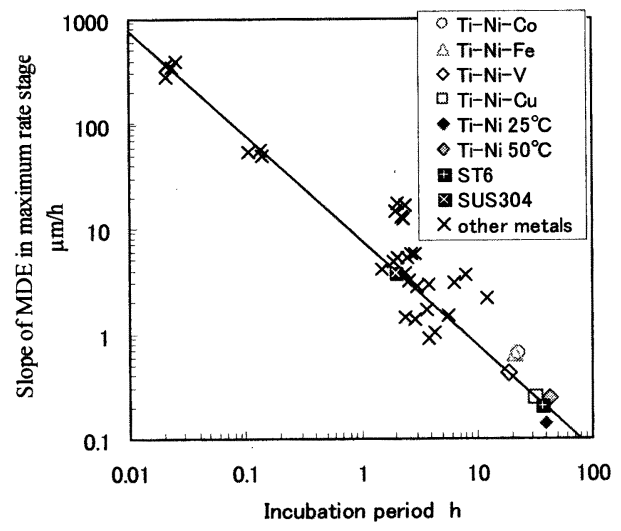

Fig. 3 Relation between incubation period and slope of MDE in maximum rate stage

\section{3. 試験結果および考察}

$3 \cdot 1 \mathrm{Ti}-\mathrm{Ni}$ 系形状記憶合金の壊食挙動図 2 は, $\mathrm{Ti}-\mathrm{Ni}$ 系形状記憶合金と各種参照材料のキャビテー ション壊食試験の $\mathrm{MDE}$ (平均壊食深さ)曲線である。 いずれの試験材料も，MDE は壊食速度が極めて小さ い潜伏期を過ぎた後急激に増加し, 直線的に増加する 最大速度期に至る. MDE 曲線の最大速度期の傾きの 延長線と時間軸との交点から求めた潜伏期は, SUS 304 では 2 時間程度であるのに対し, 第三元素を 含む $\mathrm{Ti}-\mathrm{Ni}$ 系形状記憶合金では, Ti-Ni-Fe, Ti-Ni$\mathrm{V}$ が約 20 時間, $\mathrm{Ti}-\mathrm{Ni}-\mathrm{Co}$ が約 25 時間, $\mathrm{Ti}-\mathrm{Ni}-\mathrm{Cu}$ が約 33 時間と非常に長い.しかし, Ti-Ni 系形状記 憶合金の潜伏期は, 参照材料の $\mathrm{Ti}-\mathrm{Ni}$ 形状記憶合金 やST 6(約 40 時間) と比較すると半分程度である. ま た, $\mathrm{Ti}-\mathrm{Ni}$ 系形状記憶合金の最大速度期のこう配 $\left(\mathrm{Ti}^{-}\right.$ $\mathrm{Ni}-\mathrm{Co}, \mathrm{Ti}-\mathrm{Ni}-\mathrm{Fe}$ は $0.64 \mu \mathrm{m} / \mathrm{h}, \mathrm{Ti}-\mathrm{Ni}-\mathrm{V}$ は 0.42 $\mu \mathrm{m} / \mathrm{h}, \mathrm{Ti}-\mathrm{Ni}-\mathrm{Cu}$ は $0.25 \mu \mathrm{m} / \mathrm{h})$ は $\mathrm{Ti}-\mathrm{Ni}$ 形状記憶合 金 $(0.14 \mu \mathrm{m} / \mathrm{h})$ の約 2 5 倍のこう配であるが, SUS $304(3.9 \mu \mathrm{m} / \mathrm{h})$ と比較すると約 $1 / 16 \sim 1 / 6$ であ る.このことから, 第三元素を添加した Ti-Ni 系形 状記憶合金は Ti-Ni 形状記憶合金ほどではないが, 優れた耐壊食性を示すことがわかる，また，Ti-Ni 形 状記憶合金では, $25^{\circ} \mathrm{Cで}$ 試験したマルテンサイト状態

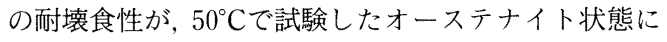
比べて優れている.マルテンサイト状態の $\mathrm{Ti}-\mathrm{Ni}-\mathrm{Cu}$ の耐壊食性がオーステナイト状態の他の $\mathrm{Ti}-\mathrm{Ni}$ 系形 状記憶合金よりも優れていることと符合している.

図 3 は, これまで本研究室で得られたさまざまな材 料のキャビテーション壊食試験の結果から, 潜伏期と $\mathrm{MDE}$ の最大速度期の傾きの関係 ${ }^{(7)}$ を示したものであ

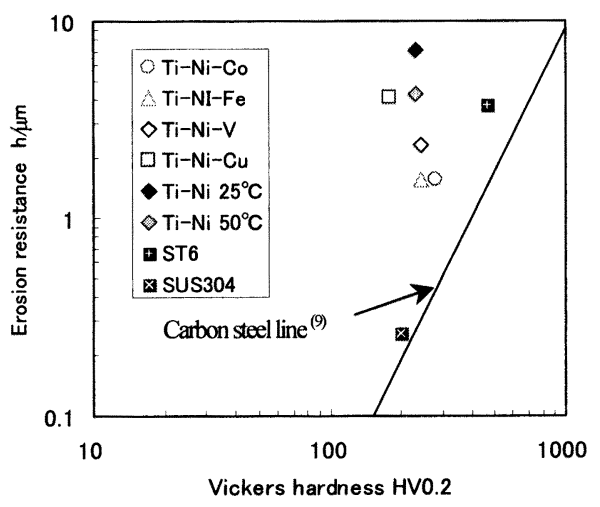

Fig. 4 Relation between Vickers hardness and erosion resistance 
る. 潜伏期の長い材料ほど傾きが緩やかになる傾向が あり， Ti- $\mathrm{Ni}$ 系形状記憶合金の潜伏期と MDE の最大 速度期の傾きの関係も，すでに報告した金属のデータ を通る直線の延長線上に位置している.

これまで金属材料のキャビテーション壊食抵抗は, 機械的性質の中の硬さと良い相関性を示すことが報告 されている( ${ }^{(8)}$. 壊食抵抗は MDEの最大速度期の傾き の逆数, すなわち, $1 \mu \mathrm{m}$ を壊食するのに要する時間と して定義した. 図 4 は, ビッカース硬さと壊食抵抗の 関係を示したものである。図中の直線は, 本研究室で 構築したデータベースを基に炭素鋼 68 種類を解析し た結果から得られた壊食抵抗の基準線である(9). 第三 元素を添加した $\mathrm{Ti}-\mathrm{Ni}$ 系形状記憶合金は, $\mathrm{Ti}-\mathrm{Ni}$ 形 状記憶合金の壊食抵抗に比べて $1 / 4 \sim 1 / 2$ 程度である が, 同じ硬さの炭素鋼と比較して約 $4 \sim 27$ 倍, SUS 304 の約 6〜16 倍の壊食抵抗を持つことがわか る. 炭素鋼の壊食抵抗は硬さの2.4 乗に比例して増加 するが, $\mathrm{Ti}-\mathrm{Ni}$ 系形状記憶合金の壊食抵抗は硬さとあ まり良い相関性を示さない.

キャビテーション気泡崩壊圧による材料の加工硬化 の影響を調べるために, 試験前と試験後の試験材料の 硬さを測定した。表 4 に試験前と試験後のビッカース 硬さと, 硬さの増加率を示す.試験後の硬さは処女面

Table 4 Change in hardness by cavitation

\begin{tabular}{|c|c|c|c|}
\hline \multirow{2}{*}{ Material } & \multicolumn{2}{|c|}{ HV0.2 } & $\begin{array}{c}\text { Increasing } \\
\text { ratio } \\
\%\end{array}$ \\
\cline { 2 - 3 } & Virgin sureface & Eroded surface & 13.1 \\
\hline Ti-Ni-Co & 282 & 319 & 13 \\
\hline Ti-Ni-Fe & 244 & 294 & 20.5 \\
\hline Ti-Ni-V & 242 & 282 & 16.5 \\
\hline Ti-Ni-Cu & 179 & 217 & 21.2 \\
\hline Ti-Ni & 210 & 233 & 11.0 \\
\hline ST6 & 466 & 733 & 57.3 \\
\hline SUS304 & 198 & 240 & 21.2 \\
\hline
\end{tabular}

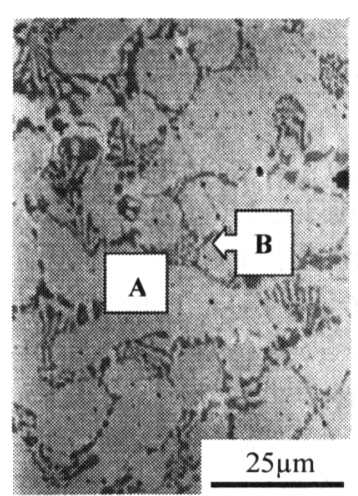

(a) $0 \mathrm{~h}$

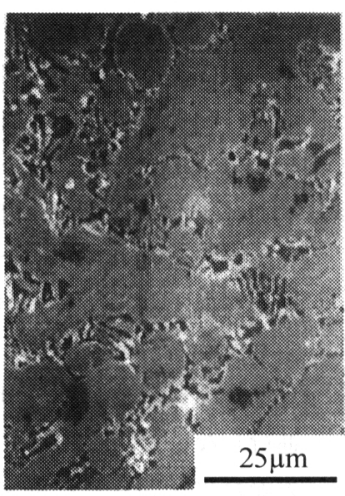

(b) $5 \mathrm{~h}$

と壊食領域の境界近傍で測定した。 ST 6 は硬さの増 加率が約 $60 \%$ と著しく加工硬化するが, $\mathrm{Ti}-\mathrm{Ni}$ 系形 状記憶合金, Ti-Ni 形状記憶合金および SUS 304 は, 加工硬化による硬さの増加率が約 $20 \%$ とほぼ同じで ある。 $\mathrm{Ti}-\mathrm{Ni}$ 系形状記憶合金はステライトほど加工 硬化しないので, 加工硬化後の硬さを用いても壊食抵 抗を整理することができない。これは $\mathrm{Ti}-\mathrm{Ni}$ 系形状 記憶合金が双晶変形とすべりの組合せで塑性変形し, すべりのみで変形する他の材料と同様に硬さで整理す ることができなかったものと考えられる。

図 5 は, マルテンサイト変態開始温度と壊食抵抗の 関係を示したものである。壊食試験の液温が $25^{\circ} \mathrm{C} て ゙$ あるので Ti-Ni-Co, Ti-Ni-Fe, Ti-Ni-V はオース テナイト状態, $\mathrm{Ti}-\mathrm{Ni}$ おび $\mathrm{Ti}-\mathrm{Ni}-\mathrm{Cu}$ はマルテンサ イト状態で壊食試験を行っていることになる、マルテ ンサイト状態の耐壊食性がオーステナイト状態に比べ て優れていることがわかる。しかし, 同一マルテンサ イト状態でも耐壞食性に相違が認められる.

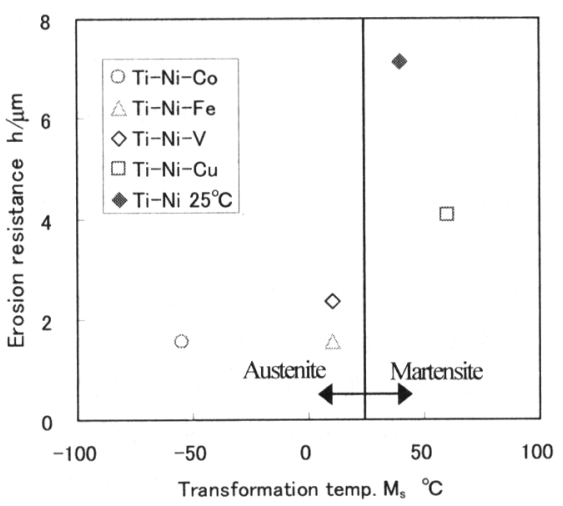

Fig. 5 Relation between martensitic transformation start temperature and erosion resistance

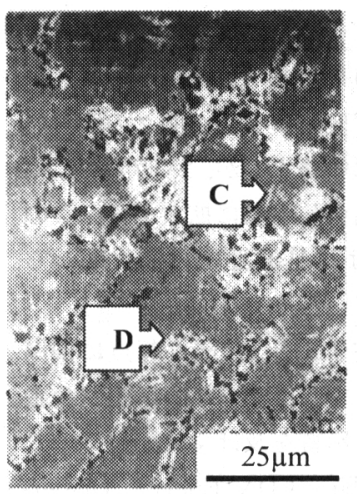

(c) $10 \mathrm{~h}$

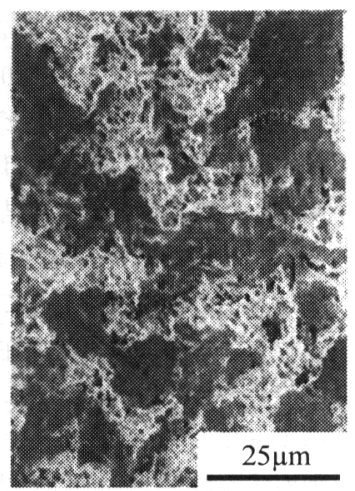

(d) $20 \mathrm{~h}$

Fig. 6 SEM photographs of eroded surface of ST 6 


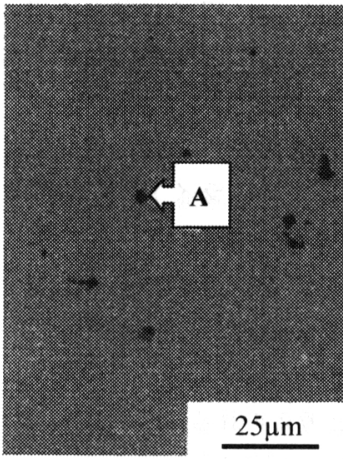

(a) $0 \mathrm{~h}$

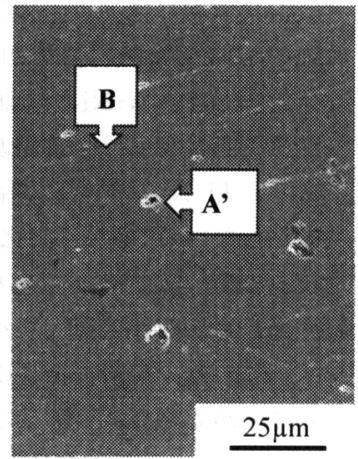

(b) $5 \mathrm{~h}$

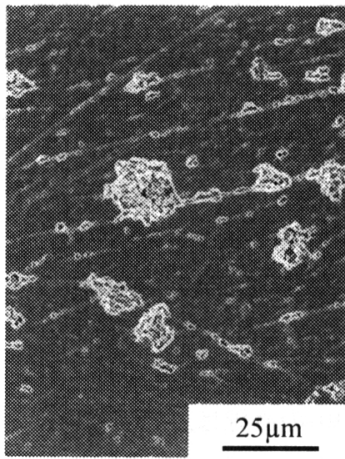

(c) $15 \mathrm{~h}$

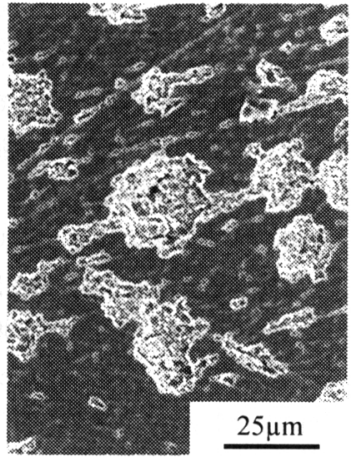

(d) $20 \mathrm{~h}$

Fig. 7 SEM photographs of eroded surface of $\mathrm{Ti}^{-} \mathrm{Ni}-\mathrm{Co}$

$3 \cdot 2$ 壊食面の観察と壊食速度の評価 $\mathrm{Ti}-\mathrm{Ni}$ 系 形状記憶合金の壊食機構を明らかにするために，Ti $\mathrm{Ni}$ 系形状記憶合金と参照材料のST 6 の壊食面を走 査形電子顕微鏡 $(\mathrm{SEM})$ で観察した。网 6 は, ST 6 の 同一箇所の壊食の進展のようすを示したものである。 処女面 [図6(a)] はコバルトのマトリックス $(\mathrm{A}) に$ カーバイド (B)が析出する亜共晶組織である。 5 時間 後 [図 6(b)] にはマトリックス部分にすべりが生じ， 10 時間後 [図 6(c) ] には,さらに明りょうになった すべり $(\mathrm{C})$ が見られ，すべりがカーバイドで阻止され ることによってマトリックスとカーバイドの界面付近 (D)で壊食が始まる。20時間後 $[$ 図6(d)] 以後は, マトリックスが壞食されるようになる。

図 7 は, $\mathrm{Ti}-\mathrm{Ni}$ 系形状記憶合金の一例として $\mathrm{Ti}$ $\mathrm{Ni}-\mathrm{Co}$ の壊食過程を SEM で観察した結果である。 処女面 [図7( a ) ] にはいくつかの黑色の欠陷 $(\mathrm{A})$ が 存在しており, 5 時間後 [図 7 ( b ) ] には欠陥を起点 にした壊食痕 $\left(\mathrm{A}^{\prime}\right)$ やすべり (B)の発生が見られ、初期 欠陥以外の所からも微小な壊食痕が発生しているのが 観察できる. 15 時間 [図 7 ( c ) ] になると表面に多数 のすべりが現れはじめ, 20 時間後 [図 7(d)] にはす ベりの発生状況はほとんど変わらないが個々の壊食痕 が大きくなっている，図は省略するが，25時間後には 隣接した壊食痕どうしが結合し急激に拡大する。この ような急速な壊食の進行は, MDE 曲線の潜伏期から 加速期への移行と対応している.

材料の表面に欠陥が存在すると，欠陥を起点に損傷 を受けやすくなる(2). そこで, Ti-Ni 系形状記憶合金 のキャビテーション壊食に影響を及ぼす欠陥について 考察するため, 処女面の欠陷を EDX (Energy Disper sive $\mathrm{X}$-ray analyzer, エネルギー分散形 X 線分析装 置)で成分分析を行った。図 8 に一例として $\mathrm{Ti}^{-} \mathrm{Ni}-$

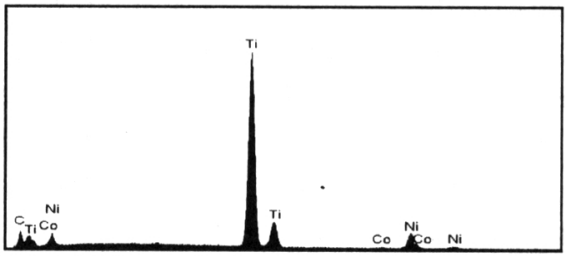

(a) Normal area

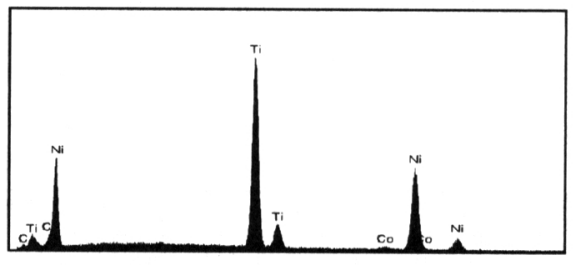

(b) Defect area

Fig. 8 Element analysis of $\mathrm{Ti}^{-} \mathrm{Ni}^{-} \mathrm{Co}$

Co の成分分析の結果を示す. 処女面 [図 8(a)] は $\mathrm{Ti}, \mathrm{Ni}$ および第三元素の Co が検出される. 欠陷部 分 [図 $8(\mathrm{~b})]$ は $\mathrm{Ni}$ が非欠陥部よりも多く検出され ており, 欠陉部分は $\mathrm{TiNi}_{3}$ 等の金属間化合物が析出し ているものと考えられる。それぞれの材料の処女面を SEM で観察したところ, Ti-Ni-Co, Ti-Ni-Fe は多 数の欠陥が存在するが, $\mathrm{Ti}-\mathrm{Ni}-\mathrm{Cu}$ は $\mathrm{Ti}-\mathrm{Ni}-\mathrm{Co} や$ $\mathrm{Ti}-\mathrm{Ni}-\mathrm{Fe}$ と比較して欠陷は少なく, $\mathrm{Ti}-\mathrm{Ni}-\mathrm{V}$ は微小 な欠陥が点在するだけであった。また， $\mathrm{Ti}-\mathrm{Ni}$ 形状記 憶合金にも微小な欠陥が存在していた。 SEM 観察に より処女面とキャビテーション壊食試験を 1 時間行っ た壊食面を比較すると, 壊食が進行した欠陥と壞食が 進行しない欠陥があった。そそのため, 壊食が進行した 欠陥だけを壊食に影響する欠陥とした。図 9 にSEM 写真から計測した欠陷密度 $\left(1 \mathrm{~mm}^{2}\right.$ 当たりの欠陥の個 数) と壊食抵抗の関係を示す. 欠陌密度が増加するに 
つれて壊食抵抗が小さくなる傾向があるが, $\mathrm{Ti}-\mathrm{Ni}-$ $\mathrm{Cu}$ は, 欠陥密度が高い割には壊食抵抗が大きいこと がわかる。

欠陥の数だけでなく壊食面積の拡大状況も壞食に影 響すると考え, 5 時間ごとに SEMにより同一の壊食 痕を観察した。壊食痕の形状はさまざまであるので, 壊食痕の形状をだ円形とみなし, だ円形の長径と短径 から壊食痕の面積を求めた。それぞれの $\mathrm{Ti}-\mathrm{Ni}$ 系形 状記憶合金について 5 箇所の欠陷の大きさを計測し, その平均值を求めた. 25 時間以後は, 隣接した壊食痕 どうしが結合するために, 壊食痕の面積を計測するこ とができなかった. 図 10 はこの結果を示したもので, 壊食痕の面積は 10 時間までは緩やかなこう配で増加 するが，その後こう配が急激に増加する．傾きが最大 になっている 15〜20 時間の間で壊食の面積の拡大す る速度を求めた。 久陷の面積拡大速度は, $\mathrm{Ti}-\mathrm{Ni}-\mathrm{Co}$ は $54 \mu \mathrm{m}^{2} / \mathrm{h}, \mathrm{Ti}-\mathrm{Ni}-\mathrm{Fe}$ は $40 \mu \mathrm{m}^{2} / \mathrm{h}, \mathrm{Ti}-\mathrm{Ni}-\mathrm{V}$ は 18 $\mu \mathrm{m}^{2} / \mathrm{h}, \mathrm{Ti}-\mathrm{Ni}-\mathrm{Cu}$ は $9 \mu \mathrm{m}^{2} / \mathrm{h}$ であり, マルテンサイ ト状態の $\mathrm{Ti}-\mathrm{Ni}-\mathrm{Cu}$ の面積拡大速度は, 他のオーステ

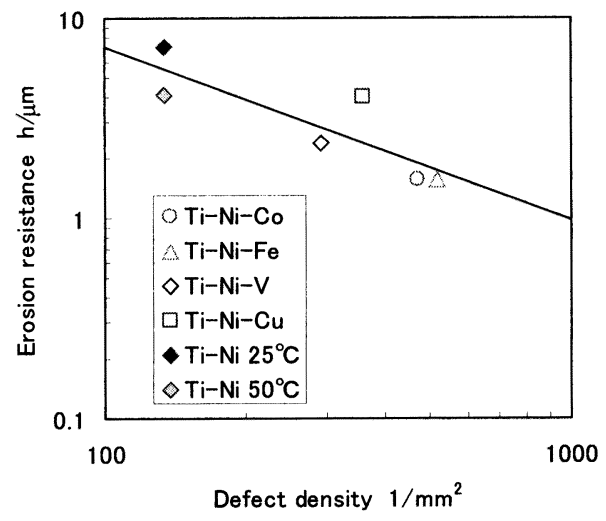

Fig. 9 Relation between defect density and erosion resistance

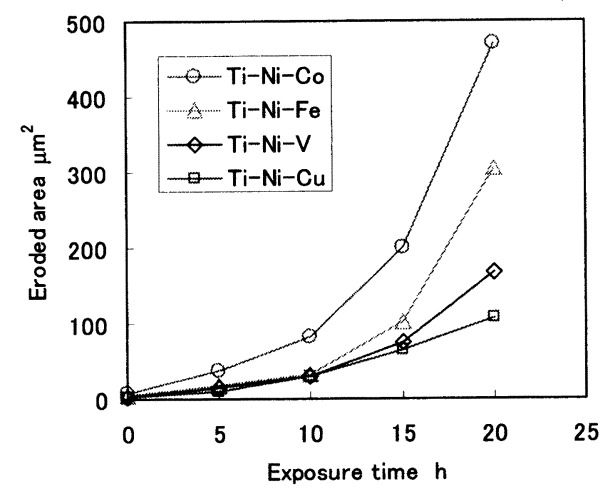

Fig. 10 Variation in eroded area
ナイト状態の拡大速度よりも小さい. $\mathrm{Ti}-\mathrm{Ni}-\mathrm{Cu} の マ$ ルテンサイト状態の弾性係数は, 表 3 に示すように $2.5 \mathrm{GPa}$ であるのに対して, 他の $\mathrm{Ti}-\mathrm{Ni}$ 系形状記憶 合金のオーステナイト状態の $20 \sim 27 \mathrm{GPa}$ に比べて約 1/10 倍である.このため, マルテンサイト状態の壊食 速度が低いのは, プラスチック材料と同様に弾性率の 低下による材料表面へ作用する気泡崩壊圧が小さくな る(10) ためであると考えられる。

壞食に及ぼす欠陥密度と壊食面積の拡大速度を同時 に考慮するため, 久陥密度と壊食面積の拡大速度の積 を求め, 壊食抵抗との関係で表示した. 図 11 に示す ように, 久陥密度, 久陷の面積拡大速度が増加するに つれて壊食抵抗が低下するという良い相関性が認めら れる. $\mathrm{Ti}-\mathrm{Ni}$ 系形状記憶合金の壊食抵抗は欠陥密度 と壊食面積の拡大速度の積に影響を受けることがわか る.

\section{4. 結言}

$\mathrm{Ti}-\mathrm{Ni}$ 形状記憶合金に第三元素を加えた $\mathrm{Ti}-\mathrm{Ni}$ 系 形状記憶合金のキャビテーション壊食試験を行い, MDE 曲線, SEM 観察による壊食面をそれぞれの材料 で比較して考察した結果, 次のようなことが明らかに なった。

（1）第三元素を添加した Ti-Ni 系形状記憶合金 は, SUS 304 と比較して潜伏期は約 10〜15 倍, 壊食 抵抗は約 6〜16 倍の優れた耐壊食性を示す.

（2） $\mathrm{Ti}-\mathrm{Ni}$ 形状記憶合金に第三元素を添加する ことにより機械的性質, 変態温度を変化させることが できるが, 耐壊食性は第三元素を含まない $\mathrm{Ti}-\mathrm{Ni}$ 形 状記憶合金よりもやや低下する。

（3）マルテンサイト状態の壊食抵抗はオーステナ

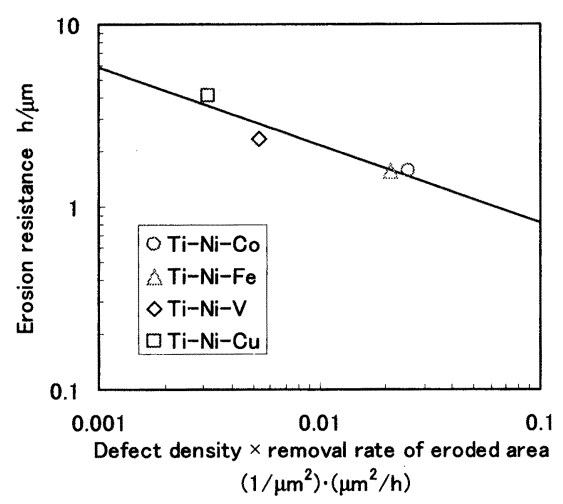

Fig. 11 Erosion resistance as a function of defect density and removal rate of eroded area 
イト状態に比べて優れる。

（4） $\mathrm{Ti}-\mathrm{Ni}$ 系形状記憶合金の壊食抵抗は硬さで 整理することはできず, 材料中の欠陷密度と壊食面積 の拡大速度に依存する。

$\mathrm{Ti}-\mathrm{Ni}$ 系形状記憶合金素材は大同特殊鋼(株)の森 井浩一氏より提供を受けた。記して謝意を表する.

\section{文献}

(1) Okada, T. and Hattori, S., Science of Machine, Vol. 50, No. 7 (1998), pp. 787-795 (in Japanese).

(2) Nakao, E. and Hattori, S., Fundametal Study on Cavitation Erosion Using a NiTi Shape Memory Alloy, Transactions of the Japanese Society of Mechanical Engineers, Series A, Vol.64, No.626 (1998), pp. 2555 2560

(3) Hattori, S. and Toukoh, M., Cavitation Erosion Ti-Ni Shape Memory Alloy Coationg, Transactions of the Japanese Socicty of Mechanical Enginecrs, Scries A. Vol. 69, No. 678 (2003), pp. 351-356.
(4) Nemoto, A., Shape Memory Alloys, (in Japanese), (1989), p. 75, 79, Nihon Kikai Kyoukai.

(5) Sakuma, T. et al., Effects of Additional Elements on Erosion and Wear Characteristics in $\mathrm{Ti}-\mathrm{Ni}$ Shape Memory Alloy, Corrosion Engineering, Vol. 52 (2003). pp. 643-649 (in Japanese).

(6) ASTM Designation G 32-98, (2000), pp. 107-120. Annual Book of ASTM Standards.

(7) Hattori, S. and Maeda, K., Formulation of Cavitation Erosion Behavior based on Logistic Analysis, Transactions of the Japanese Society of Mechanical Engineers, Series A, Vol.71, No. 708 (2005), pp. 1175-1181.

(8) Heymann, F. J., ASTM Spccial Technical Publication. No. 474 (1970), pp. 212-248.

(9) Hattori, S. and Ishikura, R., Construction of Database on Cavitation Erosion and Anlysis of Carbon Steel Data. Transactions of the Japancise Socicty of Mechani. cal Engineers, Scries A, Vol.70, No. 689 (2004), pp. $107-113$.

(10) Hattori, S. et al. Cavitation Erosion Resistance of High Polymer Materials, Transactions of the Japanese Socicty of Mechanical Engincers, Scric's A, Vol. 71, No. 705 (2005), pp. $128-133$. 